\title{
PENDAMPINGAN PENGEMBANGAN KUB (KELOMPOK USAHA BERSAMA) BATIK MALANGAN DI KOTA MALANG
}

\author{
Lita Dwipasari ${ }^{1)}$, Totok Subianto ${ }^{2)}$ \\ ${ }^{1,2)}$ D-III Keuangan Perbankan, Universitas Merdeka Malang \\ 1)e-Mail : lita.dwipasari.@unmer.ac.id \\ 2)e-Mail : totok.subiyanto.@unmer ac.id
}

\begin{abstract}
ABSTRAK
Kerajinan batik sudah menjadi salah satu industri kreatif di Indonesia. Batik bila ditekuni secara professional akan 42dapat menjadi salah satu "Soko Guru" bagi perekonomian. Dikota Malang, animo masyarakat memakai batik sudah mulai meningkat. Sementara itu batik malangan sendiri belum popular karena keberadaannya yang masih baru. Desain etnik yang dibuat berdasarkan sejarah dan potensi daerah memang belum seberapa banyak bila dibandingkan dengan batik Jogja dan Solo sehingga dibutuhkan bantuan untuk mengeksplorasi potensi khas kota Malang tersebut dalam desain batik yang lebih bervariasi (ethno modern). Kelompok Usaha Bersama (KUB) batik yaitu KUB batik Blimbing (batik Reni) dan batik Tlogomas yang berada di kota Malang adalah salah satu contoh kelompok ibu-ibu PKK yang secara bersama-sama mendirikan usaha kerajinan Batik Malangan untuk meningkatkan perekonomian keluarga. Namun Pembuatan batik mereka masih sederhana sehingga belum dapat menjangkau segmen pasar yang lebih luas. Dengan melalui pendampingan tentang proses produk dan desain batik karakter, perhitungan harga produksi diharapkan dapat meningkatkan produksi dan pemasaran batik dan dapat mendongkrak omzet penjualan batik malangan. Disamping itu pendampingan dalam kegiatan pemasaran juga dilakukan utamanya untuk mencapai segmen pasar institusi (organisasi) yang merupakan peluang bagi KUB Tlogomas dan KUB Blimbing (batik Reni).
\end{abstract}

Kata Kunci : Pendampingan, KUB, Batik Malangan

\section{PENDAHULUAN}

\section{Analisis Situasi}

Pada tanggal 2 Oktober 2009 UNESCO mengakui keberadaan batik Indonesia sebagai warisan budaya dunia yang keberadaanya perlu dilestarikan. Batik juga meningkatkan ekonomi masyarakat karena batik adalah salah satu industri kreatif yang diharapkan mampu bersaing dipasar global. Oleh karena itu, berbagai upaya dan program yang mendukung ke arah itu dilakukan oleh pemerintah. Bahkan setiap 2 Oktober ditetapkan sebagai hari batik nasional.

Dikota Malang, untuk meningkatkan taraf hidup masyarakat terutama masyarakat yang memiliki penghasilan menengah kebawah, pemerintah melalui Dinas perindustrian dan perdagangan (Disperindag) telah meluncurkan beberapa program yang intinya bertujuan memberdayakan masyarakat melalui penggalian potensi yang dimiliki daerah untuk kemudian dikembangkan secara bersama-sama. Kelompok usaha seperti ini diharapkan akan menghasilkan suatu organisasi usaha yang mandiri. Mereka tergabung dalam Kelompok Usaha Bersama (KUB). Dasar inilah yang kemudian menjadi landasan terbentuknya KUB Batik Tlogomas dan KUB Batik Blimbing.
Batik buatan dari kota Malang (biasa disebut Batik Malangan) hingga saat ini masih belum begitu familiar bagi masyarakat Indonesia seperti batik jawa lainnya karena masih relatif baru. Namun penggalian motif batik Malangan masih terus diusahakan oleh pemerintah kota Malang bersama organisasiorganisasi terkait lainnya seperti dinas koperasi dan UKM, Dinas Perindustrian dan Perdagangan (Disperindag), Perbankan termasuk oleh lembaga pendidikan.

Disperindag kota Malang sendiri memiliki binaan UKM batik dan KUB Batik. KUB (Kelompok Usaha Bersama) atau biasa dipraktis KUBE adalah adalah kelompok warga yang dibentuk oleh warga sendiri yang telah dibina melalui proses kegiatan PROKESOS (Program Kesejahteraan Sosial) untuk melaksanakan kegiatan kesejahteraan sosial dan usaha ekonomi dalam semangat kebersamaan sebagai sarana untuk meningkatkan taraf kesejahteraan sosialnya. Tujuan KUB diarahkan kepada upaya mempercepat penghapusan kemiskinan, melalui :

1. Peningkatan kemampuan berusaha para anggota

KUB secara bersama dalam kelompok

2. Peningkatan pendapatan

3. Pengembangan usaha 
4. Peningkatan kepedulian dan kesetiakawanan sosial diantara para anggota KUB dan dengan masyarakat sekitar.

Dari data yang diperoleh dari Disperindag tentang perkembangan dan pembinaan UKM batik (2016) disebutkan beberapa kegiatan telah dilakukan oleh Disperindag terhadap UKM batik, namun banyak UKM yang kemudian tidak mampu lagi meneruskan kegiatannya hal ini disebabkan oleh beberapa persoalan yaitu kesulitan dalam hal pemasaran dan harga yang mahal karena proses produksi yang lama dan rumit. Sementara itu kemampuan menggambar masih terbatas dan terbilang sederhana. Tidak banyaknya pesanan membuat semangat para pengrajin menurun. Disamping itu Bank Indonesia Cabang Malang juga pernah ikut memberi bantuan dana pada KUB batik dan UKM batik dengan memberikan bantuan CSR. Namun dari jumlah 11 kelompok (UKM 9, KUB 2) pada tahun 2112, batik hanya tinggal 9 kelompok (7 UKM, 2 KUB) pada tahun 2014 yang dibina dan saat ini ditahun 2016 hanya tinggal 2 UKM dan 2 KUB yang dibina, hal ini disebabkan karena sikap dan motivasi pengrajin batik banyak yang menurun. Sasaran program pendampingan dalam kegiatan ini adalah pada KUB batik kota Malang dengan tujuan untuk meningkatkan potensi dan hasil karya membatik mereka serta meningkatkan produksi dan pemasaran batik malangan di kota Malang.

\section{Kondisi Mitra I :}

\section{KUB Batik Tlogomas}

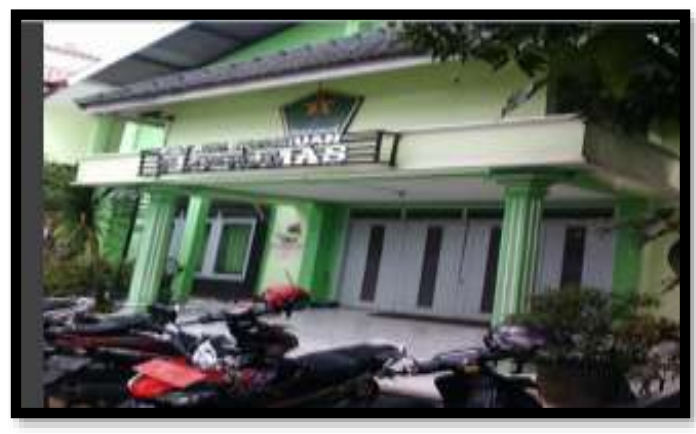

Gambar 1

Lokasi KUB Batik Tlogomas

KUB Batik Tlogomas bertempat di jalan Raya Tlogomas no 56 Kecamatan Lowokwaru Kota Malang. KUB ini berdiri pada tanggal 10 November 2014. Awal berdirinya KUB Batik Tlogomas beranggotakan 10 orang dan saat ini (sejak Februari 2015) telah beranggotakan 20 orang. KUB Tlogomas berdiri dengan Surat Keputusan Lurah. Berbekal pelatihan pewarnaan alami yang diajarkan oleh
Disperindag (12 Februari 2015) mereka mencoba memproduksi batik. Dengan cara bersama-sama kelompok yang terdiri dari ibu-ibu PKK dan sebagai ketua adalah ibu Endang Yuli Astutik ini mencari ciri khas batik yang akan dibuat yang mencerminkan potensi daerah. Maka dibuatlah motif labu kendi dan markisa (yang banyak tumbuh didaerah Tlogomas) dan situs watu gong. Area produksi batik ini tidak lagi berada di area kelurahan Tlogomas, melainkan di rumah mereka masing-masing. Kendala yang dialami kelompok ini adalah hasil batik belum optimal karena disamping desain yang masih sederhana juga menggunakan bahan yang terlalu berlebihan serta tehnik yang memakan waktu lama sehingga proses produksi batiknya memiliki harga cenderung mahal. Desain yang masih sederhana membuat banyak peluang pemasaran yang tidak terealisir. Padahal area penjualan yang dekat dengan pemerintahan dan sekolah merupakan peluang pemasaran produk batik ini, termasuk didalamnya organisasi-organisasi sosial seperti kader posyandu, kader PKK, Lansia dan para tamu-tamu di kelurahan.

Beberapa program pendanaan yang diberikan pemerintah pusat untuk memperkuat struktur modal melalui Disperindag banyak yang tidak dapat diikuti seperti KUR, LPEI dan insentif lainnya. Hal ini terjadi karena KUB kurang mengoptimalkan anggota muda dalam kelompok ini yang diarahkan untuk mampu memenuhi persyaratan yang diperlukan secara administratif.

Sementara itu ibu Yuli yang menjadi ketua KUB merangkap tenaga sosial di kelurahan akan menjadi koordinator berbagai kegiatan untuk mempromosikan produk kelompoknya.

\section{Kondisi Mitra II:}

\section{KUB Batik Blimbing (Batik Reni)}

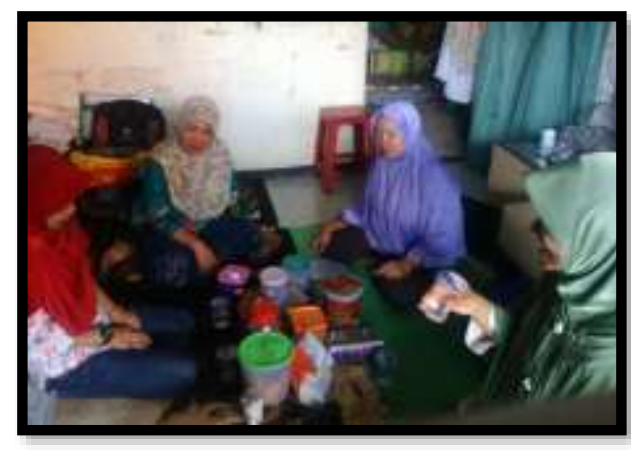

Gambar 2.

Anggota kelompok batik Reni 
KUB Batik Blimbing berada di daerah Blimbing dan terdiri dari beberapa kelompok yaitu kelompok Batik Binerkahan, kelompok Batik Jago kelompok Batik Polowijen dan kelompok batik Reni. KUB batik yang menjadi sasaran dalam program ini adalah KUB batik Blimbing dengan nama kelompoknya adalah batik Reni. Keinginan untuk belajar dan mendalami pembuatan batik membuat kelompok ini terpilih untuk daerah Blimbing sebagai sasaran dalam program ini. Kelompok ini diharapkan dapat menghasilkan produk yang sekaligus dapat mengangkat nama daerahnya sebagai kampung budaya. Sebagai ketua kelompok batik Reni adalah ibu Titik. KUB ini masih tergolong kelompok yang masih baru namun sudah dapat berkarya sendiri walaupun tehnik mengerjakannya masih termasuk kelompok awal. Pelatihan membatik awal pada kelompok batik Reni di lakukan oleh LSM yang berada didaerahnya, kemudian mereka berusaha membuat batik sendiri walaupun kesalahan beberapa kali terjadi seperti kain robek karena kekeringan, warna tidak merata keseluruh kain, warna yang tidak pada polanya dan lain-lain. Hasil mencoba akhirnya membuat mereka bisa menghasilkan batik sendiri. Dalam perjalananya kemudian batik yang mereka hasilkan terhambat karena tidak tahu hasil batik mereka akan dijual kemana. Sehingga mereka membuat batik hanya pada even-even tertentu, seperti untuk pameran.

\section{METODE KEGIATAN}

\section{Metode Pelaksanaan}

Metode kegiatan dari program ini adalah pendampingan, karena KUB yang menjadi sasaran program adalah KUB yang telah mendapatkan pengetahuan dan ketrampilan baik dari dari program pemerintah (Disperindag maupun Menkokesra) secara langsung maupun yang secara tidak langsung yaitu melalui LSM

Proses pendampingan ini melalui beberapa bidang dan tahapan tahapan, yaitu :

\section{Bidang Pengembangan produk.}

Pada bidang pengembangan produk dilakukan beberapa bagian ;

Tahap 1. Evaluasi terhadap produk batik yang dihasilkan

Tahap 2. Pelatihan terhadap proses membatik yang dilakukan dengan mempergunakan metode membatik yang praktis.

Tahap 3. Pencarian tema motif batik yang akan dibuat. Pada tahap pencarian tema motif maka yang menjadi sumber referensi adalah dengan observasi langsung, sourching internet serta pendapat anggota KUB selaku penjual yang pernah bersentuhan dengan konsumen. Hasilnya adalah tema batik yang berasal dari daerahnya masing-masing yang kemudian disebut sebagai batik karakter. Titik kritis pada tahap pengembangan produk adalah pada kombinasi motif, corak dan bentuknya.

2. Bidang manajemen

Pada bidang manajemen dilakukan beberapa hal, yaitu :

a) Kegiatan sharing untuk membandingkan biayabiaya yang dikeluarkan untuk berbagai metode membatik yang digunakan. Dalam kesempatan ini juga membantu KUB menetapkan harga bersaing.

b) Karena kelompok Batik ini adalah KUB dan berdasarkan kegiatan yang dilakukan bersamasama maka perlu dilakukan pencatatan keuangan yang teratur sehingga laporan tersebut dapat digunakan untuk mengambil keputusan baik tentang harga, tentang efisiensi, tentang persediaan dan tentang perkembangan usaha.

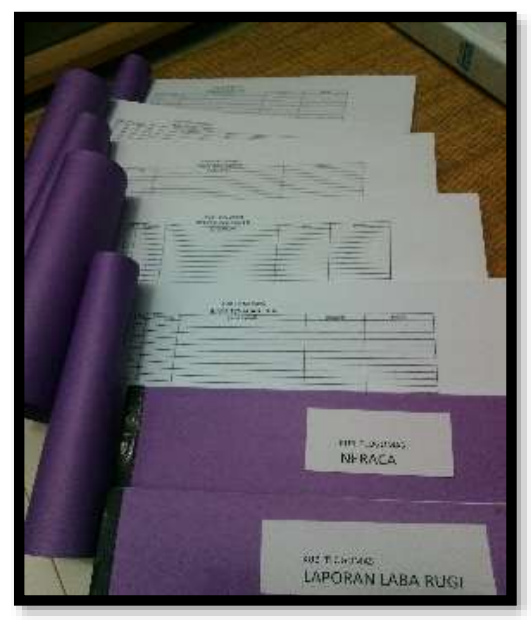

Gambar 3.

Lembar Laporan keuangan

c) Membuat kelompok batik Reni memiliki legalitas dari kelurahan sehingga kelompok tersebut dapat menjadi binaan Disperidag, masuk dalam kelompok IKM kota Malang dan dapat mengakses bantuan perkuatan struktur modal yang diberikan oleh pemerintah, baik melalui KUR, LPEI, UEP (Usaha Ekonomi mandiri) dan insentif lainnya. Sementara itu KUB Tlogomas telah memiliki legalitas dari kantor kelurahan, 
namun persyaratan bantuan permodalan adalah apabila produksi yang dilakukan cukup besar sehingga membutuhkan dana tambahan. Sementara ini KUB Tlogomas sudah mengetahui persyaratan yang diperlukan untuk di kemudian hari dapat dipenuhi sehingga bantuan pendanaan dapat diajukan.

3. Bidang pemasaran

Dibidang pemasaran yang dilakukan adalah :

a) Pelatihan pemasaran secara online bagi kelompok KUB.

b) Membuat berbagai souvenir dari batik seperti taplak, tas, sarung bantal juga dianjurkan pada kegiatan ini.

c) Pada tahapan ini pula yang dilakukan adalah memberi identitas/merk pada produk (labeling)

d) Mencari peluang pasar institusi untuk meningkatkan omzet penjualan

\section{Pelaksanaan Kegiatan}

Kegiatan yang dilakukan dalam pendampingan ini terinci sebagai berikut :

1. Bidang Pengembangan produk.

Tahap 1. Evaluasi terhadap produk batik yang dihasilkan.

Meningkatkan jumlah pembelian produk batik akan di pengaruhi oleh kualitas poduk yang dihasilkan. Oleh karena itu mencermati hasil produksi, membandingkan dengan produk yang sejenis, mencermati proses yang digunakan dapat menjadi bahan masukan tentang apa yang harus diarahkan. Dalam tahap evaluasi ini didapatkan beberapa cara yang berbeda dan kesulitan dalam melakukan proses membatik sehingga hasilnya tidak optimal. Hasil evaluasi menyebutkan ada beberapa kesulitan yang dilakukan oleh KUB batik Tlogomas : mencampur warna (bila menggunakan nepthol), tehnik pemberian waterglass yang membuat warna tidak rata, tehnik pemberian soda abu yang membuat warna agak memudar. Sementara itu KUB batik Reni masih memerlukan latihan lagi agar lebih mahir dalam mencanting.

Tahap 2. Pelatihan terhadap proses membatik yang dilakukan dengan mempergunakan metode praktis.

Pelatihan bagi kelompok batik Reni dan batik Tlogomas berbeda waktu pelaksanaannya karena mereka memiliki tingkat dan kesulitan yang berbeda. Jika batik Reni terdiri dari pembatik yang masih baru yang harus diasah lagi ketrampilannya, maka batik Tlogomas adalah kelompok pembatik yang sudah memiliki pengalaman namun masih perlu diberi tambahan pelajaran agar dapat menghasikan batik yang optimal.

Tahap pelatihan ini 5 minggu bagi batik Reni dan 2 minggu bagi batik Tlogomas.

Pelatihan dilakukan dengan proses membatik secara praktis dengan menggunakan bahan yang sama serta hasil yang lebih optimal. Pelatihan ini menggunakan remasol. Sementara itu bagi anggota KUB Tlogomas yang sering menggunakan naptol, indigasol (bahan pewarna lain) pengetahuan ini dapat menjadi perbandingan baik dari segi proses (kecepatan dan efisiensi tenaga) dan hasilnya. Termasuk bagaimana cara pemberian waterglass, pemberian abu soda dan pemberian alat bantu yang berupa timbangan digital agar mudah untuk menakar warna (jika menggunakan nepthol) Dalam kesempatan ini para anggota KUB juga diingatkan juga pentingnya memiliki kemauan mengembangkan daya melukis/membuat pola batik agar batik yang dihasilkan bervariasi.

Sebelum pelatihan, masing-masing KUB dibantu untuk membuat batik dengan karakter daerah masingmasing. Hal ini selain untuk mendorong/ memudahkan mencari inspirasi dalam membuat gambar juga dimaksudkan agar gambar tersebut dapat dikembangkan dan kemudian hari dapat menjadi ciri karakter batik didaerah mereka. Hasil pencarian menyevbutkan ada beberapa situs yang dapat digali dan menjadi karakter batik mereka.

Bagi KUB Batik Reni :
1) Watu kenong
2) Watu dakon
3) Sumur windu
4) Tanaman padi gaga
5) Bangunan rumah pertapaan
6) Kali Mewek
7) Kendedes
8) Ken Arok
9) Tunggul Ametung
10) Mpu Purwo
11) Sawah
12) Macam-macam topeng Malangan
Bagi KUB batik Tlogomas :

1) Arema

2) Malang kota yang dikelilingi gunung

3) Bunga Andong yang pernah diresmikan ibu bupati (1990) sebagai karakter batik kota Malang

4) Waluh kendi merupakan tanaman yang banyak tumbuh didaerah tersebut

5) Watu gong 


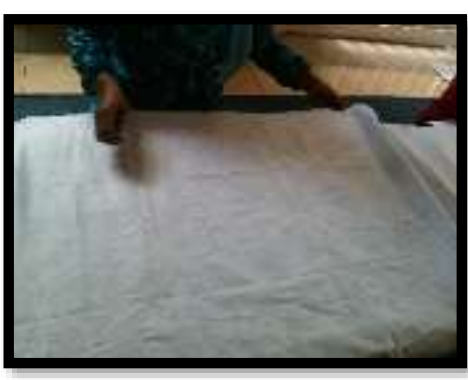

Gambar 4.

Desain batik karakter

\section{Pelatihan di KUB batik Reni}

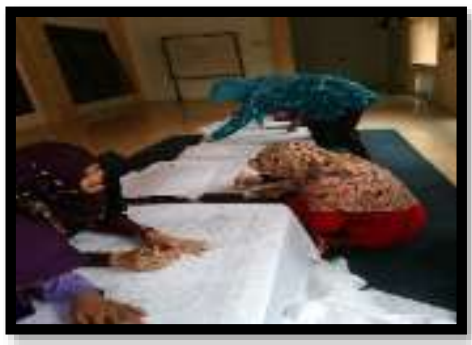

Gambar 5. Membuat pola

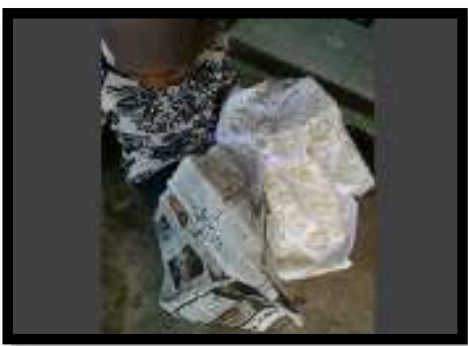

Gambar 6. Mencanting

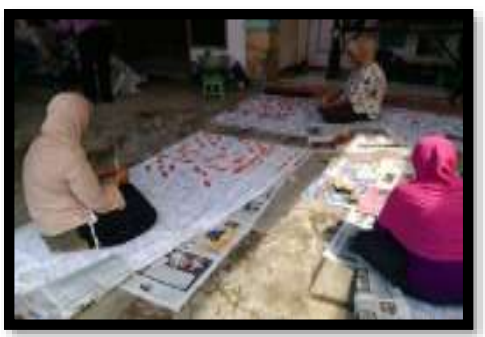

Gambar 7. Memberi warna

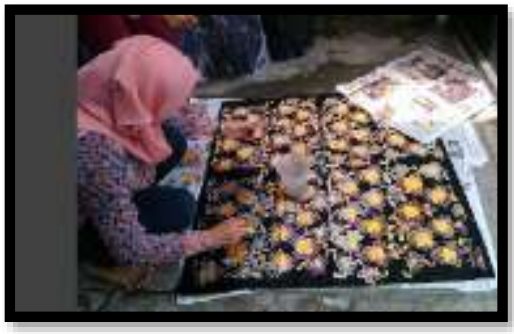

Gambar 8. Mengunci warna

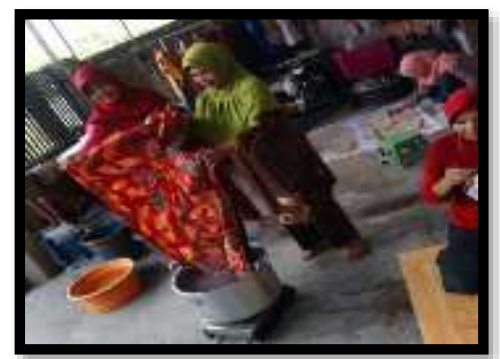

Gambar 9. Nglorod

\section{Pelatihan KUB Batik Tlogomas}

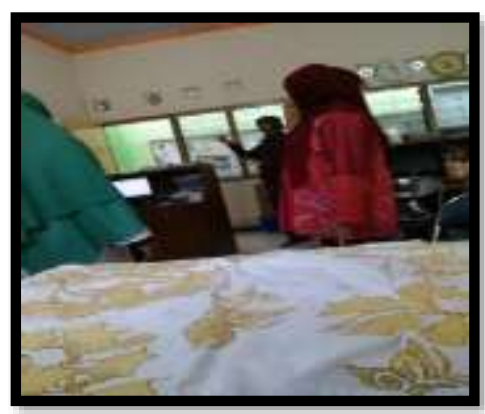

Gambar 10.

Mendiskusikan tehnik membatik

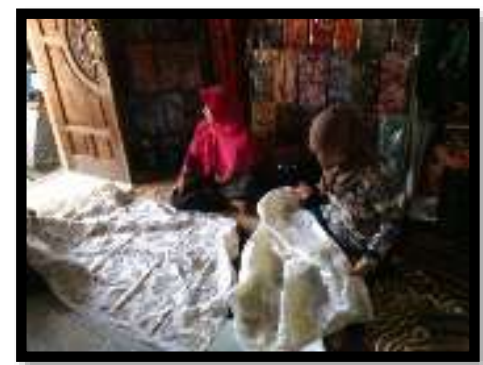

Gambar 11.

Berlatih sambil dievaluasi

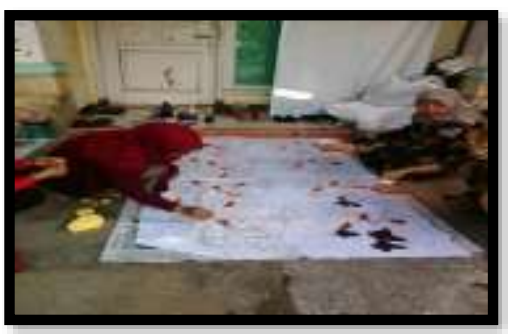

Gambar 12

Tehnik praktis (dengan remasol)

Tahap 3. Pelatihan mengolah limbah batik

Setiap anggota KUB berharap dikemudian hari batik mereka akan mengalami peningkatan penjualan. Namun bersamaan dengan itu, sangatlah tidak diharapkan akan meningkat pula pencemaran yang terjadi. Oleh karena itu, metode 
membatik praktis juga mengajarkan agar setiap anggota pengrajin batik memiliki kewajiban untuk menjaga lingkungannya dari polusi. Beberapa cara meminimalkan resiko pencemaran adalah dengan memilah antara air yang akan dibuang dengan kandungan malam yang ada. (malam bahkan dapat digunakan untuk mencanting kembali) serta menndaur ulang kembali kertas bekas membatik.

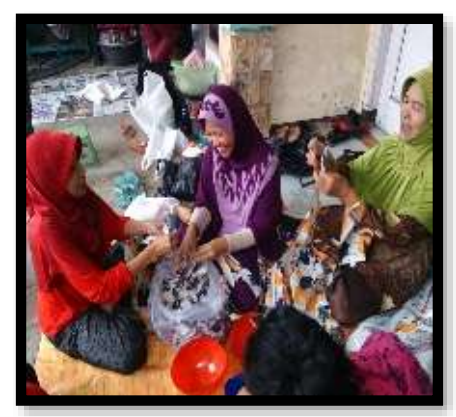

Gambar 13. Mengolah limbah

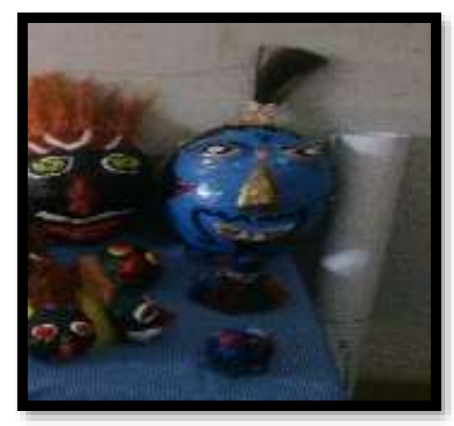

Gambar 14. Topeng dari limbah

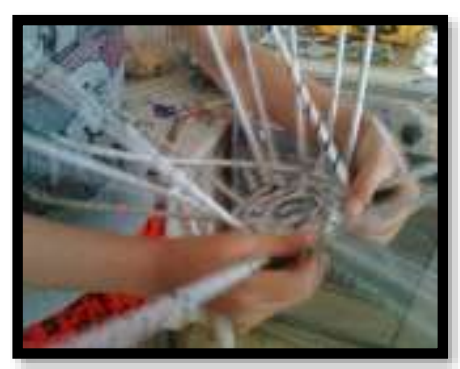

Gambar 15. Mengolah limbah

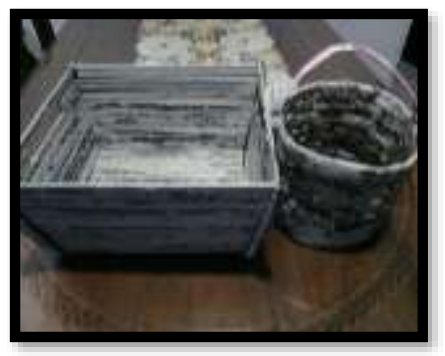

Gambar 16. Peralatan rumah tangga
Pada bidang manajemen yaitu

a) kegiatan sharing membandingkan biaya-biaya yang dikeluarkan untuk berbagai metode membatik dan bahan yang digunakan. Dalam kesempatan ini juga membantu KUB menetapkan harga bersaing. Harga batik dipengaruhi oleh kerumitan gambar,bahan pewarna yang digunakan (alami/kimia) dan jumlah warna yang digunakan.

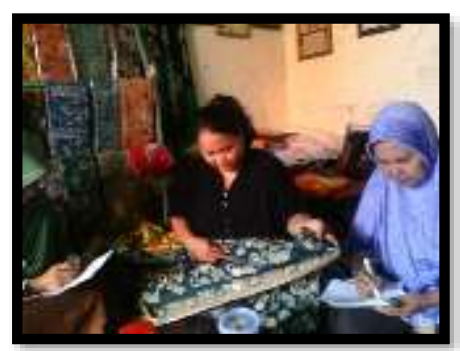

Gambar 17. Menetapkan harga

Membatik dengan metode praktis maka dapat segera diketahui hasil perhitungan biaya produksi; sebagai berikut :

\begin{tabular}{|c|c|}
\hline Kain putih $1,25 \mathrm{~m}$ & Rp. 41.000,- \\
\hline Malam & Rp. $7.500,-$ \\
\hline Pewarna(1 gram 3 bahan) & Rp. $41.000,-$ \\
\hline Waterglass & Rp. $10.000,-$ \\
\hline Gas & Rp. $5.000,-$ \\
\hline Air & Rp. 10.000.- \\
\hline Total biaya bahan & Rp. $114.500,-$ \\
\hline \multicolumn{2}{|c|}{ Jika diongkoskan pada pembatik lain } \\
\hline Membatik (gambar dan canting) & g) Rp.35.000,- \\
\hline Mewarnai dan Nglorod & $\underline{\mathrm{Rp} .25 .000 .-}$ \\
\hline Total biaya tenaga kerja & Rp. $60.000,-$ \\
\hline
\end{tabular}

Sehingga biaya produksi 1 bahan batik adalah Rp. 174.500,- atau sekitar Rp. 175.000,-.

Margin (laba) biasanya berkisar 20\%-30\%. Jika harga penjualan bahan sebesar Rp. 200.000 maka keuntungan penjual Rp.25.000,-Namun jika dikerjakan sendiri maka keuntungan dan efisiensi yang didapat sebesar Rp.85.000,- .

Dalam penetapan harga KUB harus melihat/membandingkan dengan harga dipasaran. Harga yang tertinggi dipasang adalah harga yang sama dengan pesaing. Harga terendah yang boleh ditetapkan adalah sama dengan biaya produksi.

b) Untuk membantu memperkuat struktur modal KUB maka ada beberapa informasi untuk pinjaman dan dana hibah seperti KUR dari 
perbankan dan UEP dari kementerian social. Namun karena usaha mereka belum besar (belum banyak order masuk), maka informasi ini menjadi acuan mereka untuk tahun yang akan datang apabila usaha KUB mulai berkembang. Dan menjadi acuan bagi mereka (anggota KUB) hal apa yang harus mulai mereka perhatikan.

2. Bidang Pemasaran

a) Pemasaran online.

Produk yang dihasilkan oleh KUB batik Reni dan Batik Tlogomas masih terbatas pada adanya pemesanan untuk pameran kerajinan batik. KUB batik Reni telah pernah memilki program pemasaran online, namun sehingga kini ternyata tidak aktif karena tidak pernah dipergunakan dan kesulitan mengoperasikannya. Sedangkan untuk KUB batik Tlogomas sudah mempromosikan produknya melalui IKM online (Ikatan Kerajinan Malang) yaitu secara bersama-sama dengan produk lainnya. Dalam keadaan ini, maka program memberikan pelatihan pemasaran online juga pada kedua KUB.

b) Mecari peluang pasar institusi

Sebelum membuat batik untuk seragam, maka dilakukan survey harga dan desain/motif batik yang disukai. Beberapa contoh motif batik seragam dikumpulkan untuk membuat motif pada pasar yang dituju berikut bahan dan harganya.
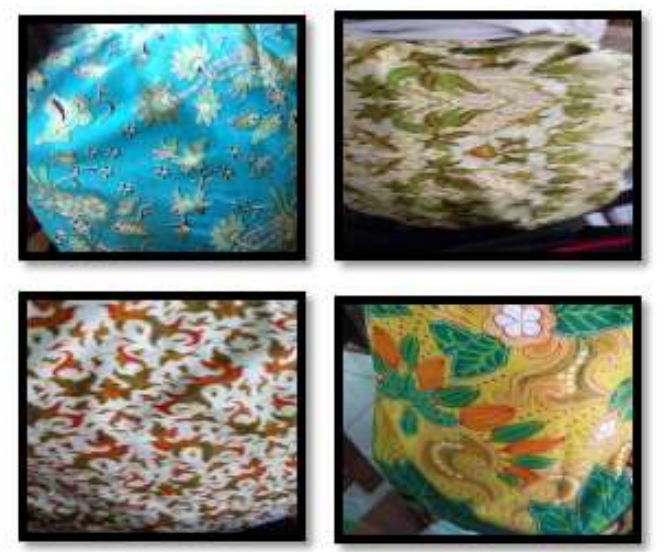

Gambar 18. Berbagai motif batik seragam

Masih jarang institusi memiliki batik seragam bagi karyawannya (hal ini berarti peluang pasar masih besar), sehingga untuk membedakan batik yang dibuat oleh KUB Reni dan Tlogomas maka dibuatlah seragam dengan simbul institusinya. Pada tahap awal dilakukan dengan membuat sampel produk yang berupa kain batik untuk dijual di lokasi penjualan. Penjualan dapat langsung atau ditawarkan di koperasi sebagai batik seragam. Beberapa pola yang sudah dibuat untuk dijadikan prototype dimana pembeli dapat memilih warnanya.Tentu saja kerumitan motif, jumlah warna dan bahan akan mempengaruhi harga , sehingga hal ini perlu dilakukan secara hati-hati.

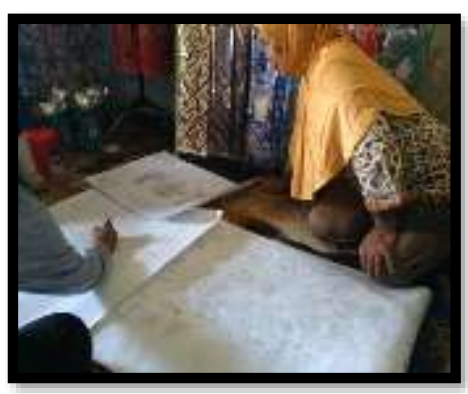

Gambar 19 Diskusi motif

c) Membuat identitas pada produk

Dalam tahap ini adalah dengan memberi pelabelan (Labeling). Labeling adalah upaya member label yang berupa informasi praktis mengenai produk. Labeling yang dibuat berisi nama produk, pembuat, alamat pembuat. Pelabelan ini dilakukan langsung pada kemasan. Hal ini dilakukan untuk lebih mudah menerima order dan berkomunikasi dengan konsumen.

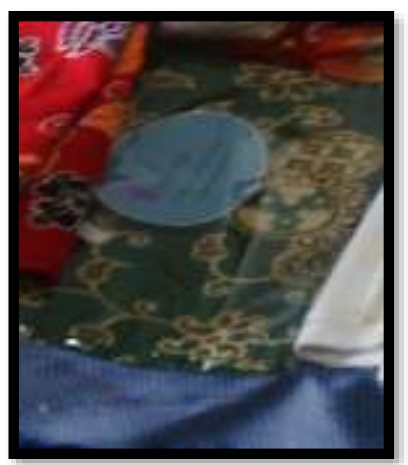

Gambar 20. Labeling

\section{HASIL DAN PEMBAHASAN}

Hasil yang dapat dicapai dari kegiatan ini bagi KUB batik adalah :

1. Mendorong semangat membatik dan membuka peluang pemasaran bagi pembatik untuk dapat mengembangkan diri. Bukan hanya dapat menjadi pengrajin batik yang pekerjaannya membatik dari pola yang diberikan, namun juga mampu menjadi usaha yang mandiri yaitu 
mampu membuat motif, mendesain sendiri sampai melakukan proses membatik dan memasarkannya.

2. Motivasi mereka juga terlihat, dimana baik pada kelompok KUB batik Reni maupun kelompok KUB Tlogomas ketrampilan membatik yang mereka miliki juga sudah mulai ditularkan pada warga sekitarnya pada kegiatan acara PKK RT. Karena metode membatik yang praktis (mudah dan efisien) maka hasilnya dapat segera terlihat. Hal ini yang memotivasi mereka untuk berani mempopulerkan batik didaerah mereka .

3. Memperkaya motif batik Malangan dengan berbagai motif yang diambil dari bentuk situs/peninggalan sejarah yang dapat menjadi motif karakter yang kemudian akan jadi ciri bagi batik masing-masing daerah

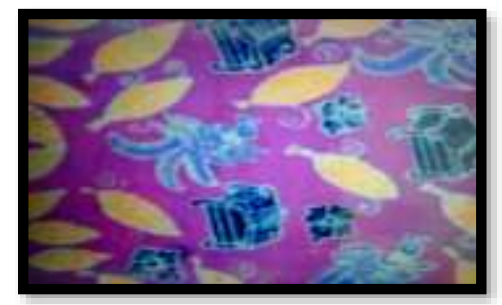

Gambar 21 Batik sumur windu

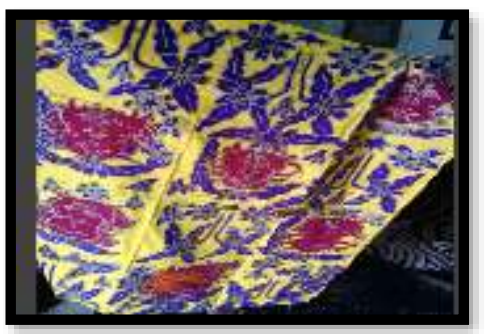

Gambar 22 Batik Arema

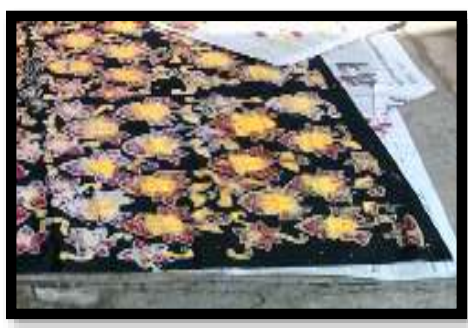

Gambar 23 Batik topeng Malangan

4. Meningkatkan omzet penjualan batik dipengaruhi juga kemampuan mendesain dengan segera motif batik yang dipesan. Omzet KUB ini dapat ditingkatkan dengan cara membuka pasar yang aru, yaitu pasar institusi.Metode membuat batik institusi agar terjangkau yaitu dengan tehnik kombinasi printing dan tulis. Sedangkan desainnya adalah kombinasi batik karakter dengan simbol institusi.

Hasilnya adalah Omzet kelompok batik Reni yang setahun 6 lembar bisa meningkat menjadi 15 lembar dalam pertengahan tahun karena mendapatkan pesanan seragam kerja.

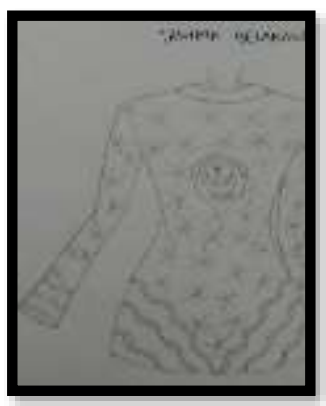

Gambar 24. Order batik untuk institusi

5. Pengembangan produk batik yang bukan hanya untuk pakaian, namun juga untuk souvenir kegiatan seperti tas, sarung bantal dan taplak meja akan dapat menambah pendapatan bagi pengrajin batik. Bagi kelompok batik Tlogomas omzet yang semula 20-25 lembar batik pertahun kini telah memperoleh order sebesar 20 lembar dalam 6 bulan dalam bentuk souvenir sarung bantal sofa batik.

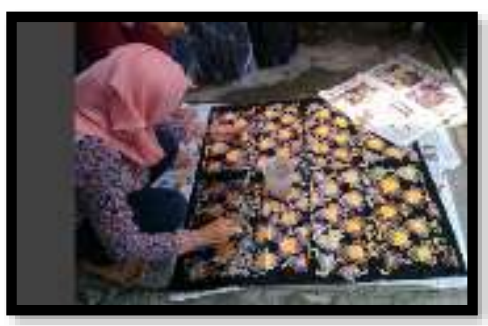

Gambar 25. Variasi batik untuk taplak meja

6. KUB Batik Reni dan batik Tlogomas memahami pentingnya Labeling pada produk dan pembukuan pada kegiatan mereka. Karena KUB biasanya memproduksi barang secara bersamasama, maka pencatatan biaya menjadi penting. Biaya yang ditimbulkan akan mempengaruhi harga sehingga harus dicatat sedemikian rupa sehingga hasil penjualan memiliki harga yang optimal.

7. Meminimalkan dampak kerusakan lingkungan akibat banyaknya pencemaran dan sampah limbah batik dengan memberikan ketrampilan mengolah limbah dari kegiatan membatik. 


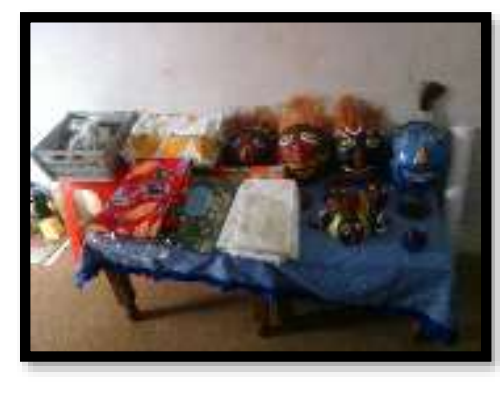

Gambar 26

batik karakter, hasil pengolahan limbah

\section{KESIMPULAN DAN SARAN}

\section{Kesimpulan}

1. Batik adalah salah satu budaya bangsa yang harus dilestarikan. Mendesain batik adalah sama dengan bercerita tentang sesuatu. Oleh karena itu menggambar batik dengan mengangkat nilai sejarah yang ada didaerahnya tidak hanya akan menghargai sejarah namun juga akan menjadi karakteristik yang bisa dikenali. Hal ini merupakan keunikan dari batik. Kemampuan membuat atau mengkombinasi motif batik merupakan kunci awal yang harus dimiliki bagi pengusaha batik agar usahnya sederhana berkembang. Kemampuan ini memang harus diasah baik dengan melihat berbagai referensi, mengikuti even-even bahkan melakukan pengamatan. Produksi batik dan pesanan dapat terhambat manakala pengusaha batik tidak memiliki ide kreatif dalam motif dan desainnya.

2. Pada masyarakat dikota Malang, batik malangan memang belum ada himbauan (dari pemerintah daerah) untuk sosialisasi dan mengajak masyarakat (karyawan, mahasiswa dan siswa) untuk menggunakan batik malangan. Padahal pada hari Jumat para karyawan diwajibkan menggunakan batik dan pada hari ulang tahun kota malang, siswa dan karyawan dianjurkan semua mengenakan batik (apa saja) atau pakaian daerah Malangan. Program dan peluang batik malangan memang masih besar karena itu dibutuhkan banyak dukungan dari berbagai pihak agar batik malangan bisa popular seperti batik lainnya dan dapat merupakan soko guru bagi peningkatan taraf ekonomi masyarakat, khususnya masyarakat dikota Malang

3. Dengan mempelajari cara membatik yang sederhana dan efisien diharapkan kelompok KUB dapat lebih produktif dan dapat menekan harga sehingga dapat berdaya saing dengan batik dari kota lainnya. Metode dalam membatik yang sederhana (metode sederhana) mampu memberikan motivasi yang tinggi terhadap ketertarikan peserta untuk menekuni bidang usaha membatik.
4. Makin tinggi hasil produksi batik, maka perhatian dan pengawasan terhadap pengelolaan limbah pada pengrajin batik harus diperhatikan, karena jangan sampai peningkatan ekonomi berdampak pada kerusakan lingkungan

\section{Saran}

1. Batik hampir menjadi kebutuhan sebagian besar dari para karyawan bahkan murid sekolah. Sehingga batik memiliki peluang ekonomi yang cukup besar untuk dikerjakan. Seperti di Jawa barat, Gubernur memberikan instruksi agar karyawan menggunakan batik hasil UKM batik didaerahnya. Demikian pula harapan pada pemerintah di Jawa Timur khususnya kota Malang, untuk adanya instruksi yang serupa agar batik Malangan dapat lebih mudah berkembang.

2. Dari hasil pengamatan dilapangan, ditemukan banyak pengrajin batik yang membuang limbahnya (utamanya limbah cair) dengan sembarangan, ada yang di halaman ada pula yang di sungai. Padahal sebagian besar dari mereka sudah pernah mendapatkan pelatihan pengelolaan limbah dari dinas perindustrian. Dalam kondisi ini disarankan pemerintah memberikan secara gratis peralatan yang dapat digunakan untuk mengurai limbah mereka seperti misalnya bak yang dilengkapi dengan pasir, kerikil, karbon aktif dan ijuk untuk netralisir limbah. Dan mengunakan aparat kampung seperti pengurus RT atau pengurus RW untuk pengawasannya.

\section{REFERENSI}

Batik malangannlyliyani $\downarrow$ September 19, 2012

Dewanti, Retno and Melati. Et.all . Pengembangan Model Daya Saing UMKM Batik melalui ECS. Jurnal Binus Business Review, 04 (01). ISSN 2087-1228 (2013)

Soekasi, Agustine.Rustina,U.et.all Tahapan pengembangan produk konveksi berbahan dasar batik pada klaster batik Pasirsari Pekalongan.2011 Seri Kajian Ilmiah. Volume 14, Nomor 2 November 2011.

Tocharman,Maman. dkk. Pengembangan Model Program Wisata Pendidikan Batik Sebagai Wahana Pembelajaran Apresiasi Masyarakat Menunjang Program Unggulan Universitas Pendidikan Indonesia

http://pasarmodal.inilah.com/read/detail/2277387/in docement-dorong-batik-cirebon-ramahlingkungan\#sthash.B6qDYqLP.dpuf

Wening, Enny et.all. Pengembangan Produk dan Strategi Pemasaran Bahan Busana Batik Bantulan dengan Stilasi Motif Etno Modern, 2014 